\title{
Baccatocarpon patanii sp. nov. A New Species of Capsular Fruit from the Deccan Intertrappean Beds of Marai Patan, Tahsil- Jiwati, Dist. Chandrapur, Maharashtra, India
}

\author{
Sanjay W. Patil ${ }^{*}$, Rajesh R. Dahegaonkar \\ Department of Botany, Dr. Ambedkar College of Arts, Commerce \& Science, Chandrapur, District- Chandrapur, Maharashtra, India
}

Received June 12, 2020; Revised October 30, 2020; Accepted November 4, 2020

\section{Cite This Paper in the following Citation Styles}

(a): [1] Sanjay W. Patil, Rajesh R. Dahegaonkar, "Baccatocarpon patanii sp. nov. A New Species of Capsular Fruit from the Deccan Intertrappean Beds of Marai Patan, Tahsil- Jiwati, Dist. Chandrapur, Maharashtra, India," Advances in Zoology and Botany, Vol. 9, No. 3, pp. 71 - 75, 2021. DOI: 10.13189/azb.2021.090302.

(b): Sanjay W. Patil, Rajesh R. Dahegaonkar (2021). Baccatocarpon patanii sp. nov. A New Species of Capsular Fruit from the Deccan Intertrappean Beds of Marai Patan, Tahsil- Jiwati, Dist. Chandrapur, Maharashtra, India. Advances in Zoology and Botany, 9(3), 71 - 75. DOI: 10.13189/azb.2021.090302.

Copyright $@ 2021$ by authors, all rights reserved. Authors agree that this article remains permanently open access under the terms of the Creative Commons Attribution License 4.0 International License

\begin{abstract}
The present paper deals with the description of a new species of petrified capsular fruit. The fruit is dicotyledonous, capsular formed from pentacarpellary, syncarpous ovary with parietal placentation. The fruit measures $0.12 \mathrm{~mm}$ in length and $0.11 \mathrm{~mm}$ in width. It is circular, pentalocular with two fertile locules having single seed in each locules and three sterile locules. The three sterile locules contain circular parenchymatous cells which act as reserve food materials or provide buoyancy for floating mechanism. The fruit wall or pericarp measures about 4.46-5.42 $\mu \mathrm{m}$ in width and is differentiated into epicarp, mesocarp and endocarp. Outer layer epicarp is multilayered having hexagonal sclerenchymatous cell and measures about $1.10 \mu \mathrm{m}$ in thickness. Middle layer mesocarp is multilayered having hexagonal sclerenchymatous cell and measures about $1.23 \mu \mathrm{m}$ in thickness and inner layer endocarp is measures about 2.13 $\mu \mathrm{m}$ in thickness. The fruit is baccate type, different from any existing living family or recorded fossil fruit from the Deccan Intertrappean beds. Therefore, it is named as Baccatocarpon patanii sp. nov. The generic name is being after the baccate nature of the fruit and the specific name indicates the locality from where it was collected.
\end{abstract}

Keywords Deccan Intertrappean, Dicotyledonous, Capsular fruit, Pentacarpellary, Syncarpous

\section{Introduction}

The present specimen incorporates the detailed morphological and anatomical description of a capsular fruit. A number of dicotyledonous fruits have been described from the Deccan Intertrappean beds of India. These are as follows- Mohgaoncarpon eyedi (Yawale, 1977), Kremocarpon aquatica (Kate, 1974), K. indicum (Upadhye, 1979), Ramanujnocarpon indicum (Kolhe, 1980), Centrospermocarpon chitaleyi (Sheikh and Khubalkar,1982), Tiliaceocarpon intertrappea (Dixit, 1984), Chitaleyocarpon deccanii (Kumar, 1984), Baccatocarpon mohgaoense (Paradkar and Dixit, 1984), Baccatocarpon sharmae (M. Bhowal and M.T. Sheikh, 2004), Baccatocarpon mohgaoense (Manchester et al. 2019), Baccatocarpon jamsavlii (Aparna M. Yadav and Bipinchandra B. Kalbande, 2020). The Present capsular fruit is the additional report of the capsular fruit from the same bed.

\section{Material and Method}

The material was very well preserved in a black chert 
collected from the Deccan Intertrappean beds of Marai Patan, Tahsil- Jiwati, Dist. Chandrapur, Maharashtra, India. A globose circular fruit was found exposed on a piece of chert in longitudinal section. After etching with hydrofluoric acid and washing with water a circular fruit with three locules were visible to the naked eyes. Serial peel sections were taken along longitudinal plane. The peels were mounted on Canada balsam mountant. Thus the fruit revealed details of morphology and anatomy through examination of fractured surface, serial sectioning and successive peels. Sony Camera (4X) and Capture Pro 4.6 exe software was used for photography and measurement of material.

\section{Description}

General Description:-The fruit is globose, circular, pentalocular, capsular fruit. The fruit measures $0.12 \mathrm{~mm}$ in length and $0.11 \mathrm{~mm}$ in width. The fruit has outer covering called as pericarp and inner part containing few locules. (Plate II, photo 7)

Pericarp:-The fruit wall or pericarp is well preserved and moderately thick and measures about 4.46-5.42 $\mu \mathrm{m}$ in thickness and has epicarp, mesocarp and endocarp (Plate II, photo 8). The Pericarp encloses two locules containing single seed and remaining two locules are without any seeds with circular parenchymatous cells (Plate II, photo 11).

Epicarp:- It is multilayered with hexagonal sclerenchymatous cell and measures about $1.10 \mu \mathrm{m}$ in thickness. (Plate II, photo 8)

Mesocarp:-It is multilayered with hexagonal sclerenchymatous cell and measures about $1.23 \mu \mathrm{m}$ in thickness. (Plate II, photo 8)

Endocarp:-It is the innermost layer of pericarp and measures about $2.13 \mu \mathrm{m}$ in thickness. (Plate II, photo 8)

Left Locule:-This locule is attached to the fruit wall and lies on the left side of the fruit. It is about $78.4 \mu \mathrm{m}$ in length and $31 \mu \mathrm{m}$ in width. The left chamber is elongated with slight tapering at both the ends and broader at the middle
(Plate II, photo 7). It contains a well-defined seed. Another locule arises in left locule from endocarp of fruit wall. New locule increases in size up to the size of old left locule due to which old left locule decreases in size. Both these locules are disappeared after few sections.

Seed:- A Single prominent seed is present in the left locule of the fruit. It measures about $78 \mu \mathrm{m} \mathrm{X} 30 \mu \mathrm{m}$ in thickness. The seed coat is bitegmic, outer seed coat is testa and inner seed coat is tegmen. The testa is about $3.05 \mu \mathrm{m}$ in thickness and tegmen measures about $1.60 \mu \mathrm{m}$ in thickness. The lumen of seed shows an empty space but at some places it contains thin walled parenchymatous cells which are preserved as endospermous cells. The embryo is not preserved. At the apex, the seed is attached to the pericarp wall by means of funicle showing parietal placentation. (Plate II, photo 12).

Right Locule:-This locule is attached to the fruit wall and lies on the right side of the fruit. It is about $76.6 \mu \mathrm{m}$ in length and $27.6 \mu \mathrm{m}$ in width. It is also elongated with slight tapering at both the ends and broader at the middle. It also contains a well-defined seed (Plate II, photo 7).

Seed:-A Single prominent seed is present in the right locule of the fruit. It measures about $76 \mu \mathrm{m}$ X $27 \mu \mathrm{m}$ in thickness. The seed coat is bitegmic, outer seed coat is testa and inner seed coat is tegmen. The testa is about $3.05 \mu \mathrm{m}$ in thickness and tegmen measures about $1.50 \mu \mathrm{m}$ in thickness. The lumen of the seed shows an empty space but at some places it contains thin walled parenchymatous cells which are preserved as endosperm cells. The embryo is not preserved. At the apex, the seed is attached to the pericarp wall by means of funicle indicating parietal placentation (Plate II, photo 12).

Dehiscence:-Along the pericarp wall the distinct gaps are seen which shows loculicidal dehiscence (Plate I, photo 6).

In between these two fertile locules inside the fruit lies an intermediate two strrile locules which opens outside from upper side. This locule contains circular parenchymatous cells which appear to be nutritive in nature or provide buoyancy for floating mechanism (Plate II, photo 11). 


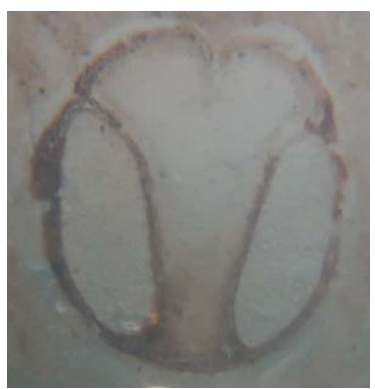

1

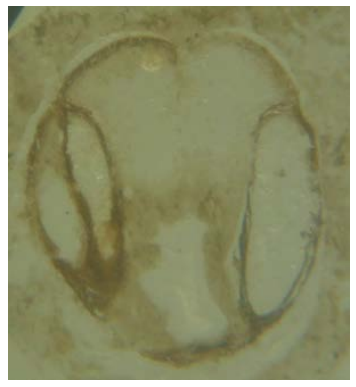

4

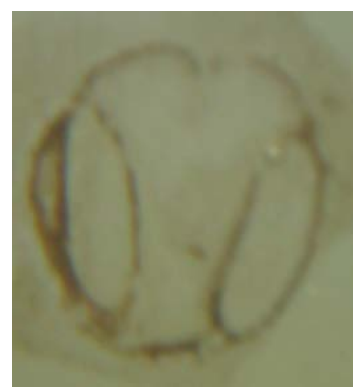

2

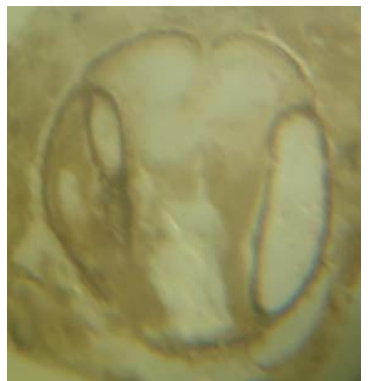

5

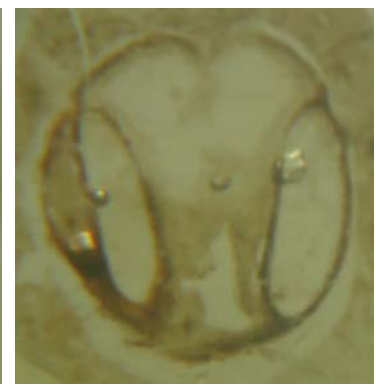

3

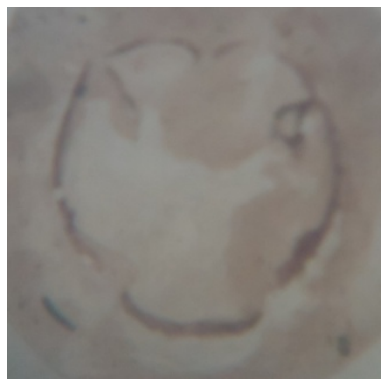

6

Plate I. Photo $1-6$

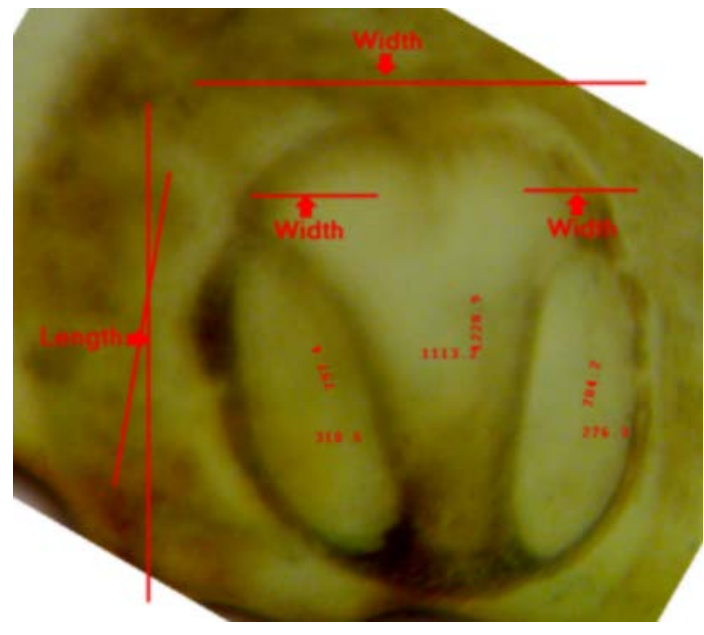

7 (Fruit-X10)

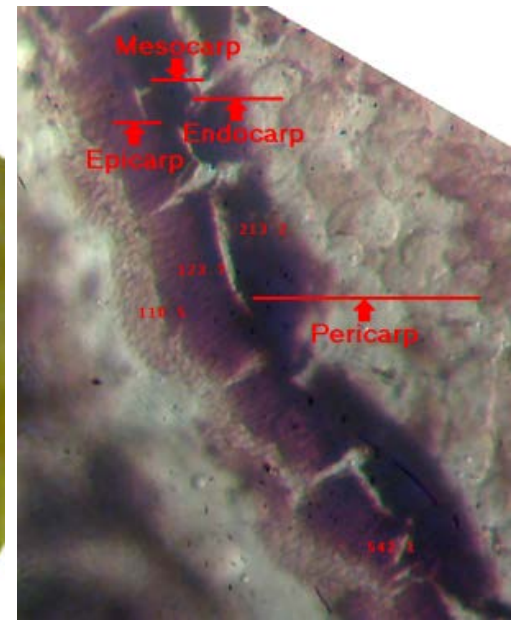

8 (Pericarp-X100)

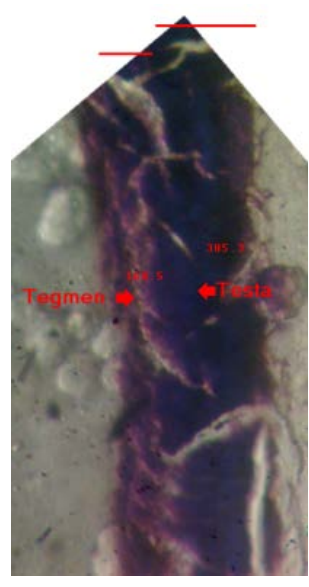

9 (Seed Coat-X100)

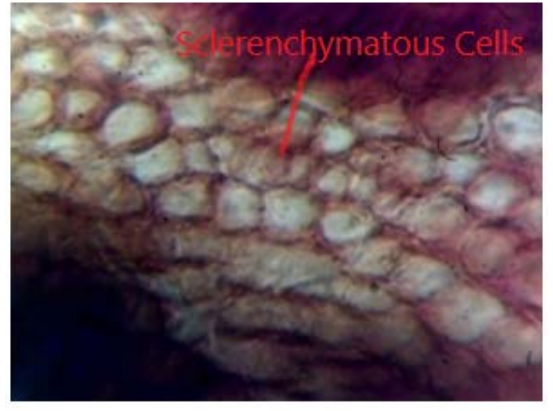

10 (Sclerenchymatous cells of mesocarp-X400)

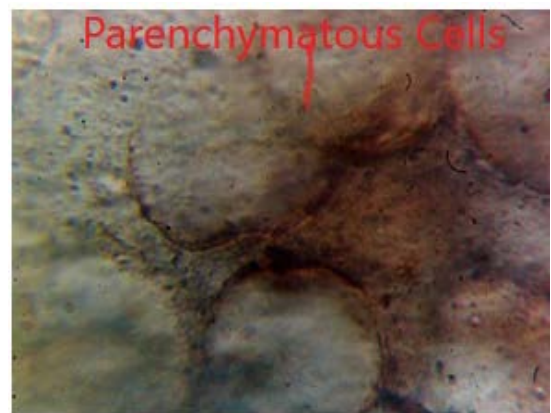

11(Parenchymatous cells of sterile locule-X400)

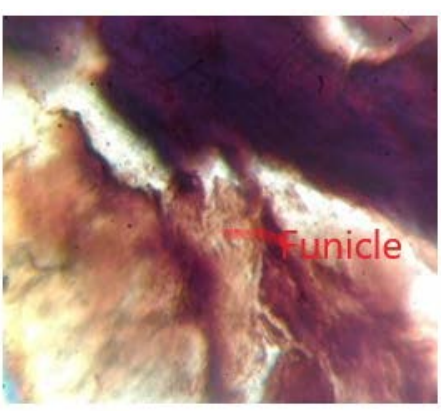

12 (Funicle-X400)

Plate II. Photo 7 - 12 


\section{Discussion and Identification}

The above described specimen revealed the following important details for its identification.

1. The fruit is circular, pentalocular with two fertile locules having single seed in each locules and three sterile locules.

2. The fruit wall is differentiated in to epicarp, mesocarp and endocarp.

3. The two sterile locules contain circular parenchymatous cells which act as reserve food material or provide buoyancy for floating mechanism.

4. The fruit shows parietal placentation.

From these characters it is evident that the described fruit was formed from pentalocular, syncarpous ovary with parietal placentation having two ovules with loculicidal dehiscence. Nature of the fruit appears to be capsular due to fleshy pericarp and dehiscence.

\section{Comparison with Fossil Fruits}

Some fossil baccate fruits have been reported from the Intertrappean beds. A comparison with them has been made as under. Mohgaoncarpon eyedi (Yawale, 1977), Kremocarpon aquatica (Kate, 1974), K. indicum (Upadhye, 1979), Ramanujnocarpon indicum (Kolhe, 1980) have been reported as a unilocular baccate fruit whereas the studied specimen is pentalocular. Tiliaceocarpon intertrappea (Dixit, 1984) was an oval, 8-10 seeded baccate fruit with fleshy pericarp and mucilage canals where as the given fossil fruit is completely different from it. Chitaleyocarpon deccanii (Sheikh and Khubalkar, 1982) is basically different from our fruit because it is unilocular with free central placenta bearing two concentric rings of small bitegmic seeds in five tiers. Baccatocarpon sharmae (M. Bhowal and M.T. Sheikh, 2004) was globose, stalked, trilocular, one fertile locule with seed and two sterile locules while the present specimen is pentalocular, without stalk and two fertile locules. Baccatocarpon mohgaoense (Paradkar and Dixit, 1984) and Baccatocarpon mohgaoense (Manchester et al. 2019) was globose, sessile, trilocular, one fertile locule with seed and two sterile locules while the present specimen is pentalocular with two fertile locules. Baccatocarpon jamsavlii (Aparna M. Yadav and Bipinchandra B. Kalbande, 2020) is elongated, hairy, trilocular with one fertile, one sterile locule and the central locule with pulpy mass. A single prominent seed present in the upper locule with parietal placentation while in the present specimen is pentalocular with two seeds and two fertile locules.

Thus the present fossil fruit does not resemble any of the fossil capsular fruits described earlier except Baccatocarpon sharmae (M. Bhowal and M.T. Sheikh, 2004), Baccatocarpon mohgaoense (Paradkar and Dixit, 1984), Baccatocarpon mohgaoense (Manchester et al. 2019) and Baccatocarpon jamsavlii (Aparna M. Yadav and
Bipinchandra B. Kalbande, 2020) with minor differences.

\section{Comparison with the Modern Taxa}

The present fossil fruit is compared with the many modern dicotyledonous families. Cruciferae, Papavaraceae, Violaceae etc. resembles in shape and size of the fruit, single seed, parietal placentation, and capsular fruits. In family Cruciferae, the fruit is unilocular but subsequently becomes bilocular by appearance of false septum. The fruits are generally siliqua or silicula with numerous ovules with parietal placentation (Rendle, 1963, Chopra, 1965). There are no similarities except for placentation. Papavaraceae is similar only in having parietal placentation. Other factors namely the fruit nature (Capsule), numerous ovules and polycarpellary condition are not seen in the specimen at all. Though Violaceae is close to the fossil in respect of unilocular, parietal placentation, capsular fruit but our fruit is pentalocular. Despite the distinctive morphology of these fruits, we have not encountered morphologically matching fruits among extant angiosperms. In our broader comparison we noted similarities with the Apialean family Torricelliaceae. In the three extant genera of Torricelliaceae, all possess three carpels with a combination of two sterile locules and one central fertile locule, and the fruits open apically by valves (Manchester et al. 2017) but our fruit have two fertile locules.

Finally summing up the comparison and discussion on the described fossil fruit it can be concluded that the present specimen under investigation does not resemble any of the living capsular fruits as well as recorded fossil fruit of the Deccan Intertrappean beds as described earlier except Baccatocarpon sharmae (M. Bhowal and M.T. Sheikh, 2004), Baccatocarpon mohgaoense (Paradkar and Dixit, 1984) and Baccatocarpon mohgaoense (Manchester et al. 2019), Baccatocarpon jamsavlii (Aparna M. Yadav and Bipinchandra B. Kalbande 2020) with minor differences hence it is named as Baccatocarpon patanii sp. nov. The generic name is being after the baccate type of fruits Baccatocarpon sharmae (M. Bhowal and M.T. Sheikh, 2004), Baccatocarpon mohgaoense (Paradkar and Dixit, 1984) Baccatocarpon mohgaoense (Manchester et al., 2019) and Baccatocarpon jamsavlii (Aparna M. Yadav and Bipinchandra B. Kalbande 2020) and specific name indicates the name of the locality from where it was collected.

\section{Diagnosis}

\section{Baccatocarpon patanii sp. nov.}

The fruit is a dicotyledonous, capsular fruit formed from pentalocular, syncarpous ovary with parietal placentation having two ovules and loculicidal dehiscence. The fruit measures $0.12 \mathrm{~mm}$ in length and $0.11 \mathrm{~mm}$ in width. The pericarp measures about 4.46-5.42 $\mu \mathrm{m}$ in width and is 
differentiates into epicarp, mesocarp and endocarp. The Pericarp enclosing two fettile locules with single seed in each locule and remaining three locules are without any seeds having circular parenchymatous cells. Epicarp is multilayered having hexagonal sclerenchymatous cell and measures about $1.10 \mu \mathrm{m}$ in thickness. Mesocarp is multilayered having hexagonal sclerenchymatous cell and measures about $1.23 \mu \mathrm{m}$ in thickness. Endocarp is the innermost layer of pericarp and measures about $2.13 \mu \mathrm{m}$ in thickness.

Holotype: SWP/Ang. Fruit/Deposited in Department of

Botany, Dr. Ambedkar College, Chandrapur.

Horizon: Deccan Intertrappean beds.

Locality: Marai Patan, Tahsil- Jiwati, Dist. Chandrapur, Maharashtra, India.

Age: ?Uppermost Cretaceous.

\section{Acknowledgements}

We are grateful to Dr. D. K. Kapgate, Ex-Head, Department of Botany, J. M. Patel College, Bhandara for examining the slides and helping in identification of the fruit.

\section{REFERENCES}

[1] Yawale N. R. (1977). Proc. 64th Ind. Sci. Cong. III-106.1977.

[2] Kate V. R. (1974). Ph. D. Thesis, Nagpur University, Nagpur.1974.

[3] Upadhe E. V. (1979). Ph. D. Thesis, Nagpur University, Nagpur.1979.
[4] Kohle P. D. (1980). Ph. D. Thesis, Nagpur University, Nagpur.1980.

[5] Dixit V. P. (1984). Ph. D. Thesis, Nagpur University, Nagpur.1984.

[6] Sheikh M. T. and Khubalkar N. V. (1982). Centrospermocarpon chitaleyii gen. et sp. nov. A new petrified fruit from the Intertrappean beds of Mohgaonkalan- India. Botanique 9(1-4). 23-38.1982.

[7] Bhowal M., Sheikh M.T. (2004). Baccatocarpon sharmae, a petrified dicot baccate fruit from intertrappean beds of Singpur. Trends Life Sci., 19(1), 25-32. 2004.

[8] Paradkar S. A., Dixit V. P. (1984). Grewia mohgaonse-a new petrified dicotyledonous fruit from the Deccan Intertrappean beds of Mohgaonkalan, Madhya PradeshIndia. Proc. Ind. Geophytology Conf., Lucknow (1983) Special Publication, 156-162.1984.

[9] Steven R. Manchester, Dashrath K. Kapgate, Deepak D. Ramteke, Sharadkumar P. Patil, and Selena Y. Smith (2019). Morphology and anatomy of the angiosperm fruit Baccatocarpon, incertae sedis, from the Maastrichtian Deccan Intertrappean Beds of India.Acta Palaeobotanica 59(2). 241-250.2019.

[10] Yadav Aparna M., Kalbande Bipinchandra B. (2020). A Trilocular Hairy Fruit from the Deccan Intertrappean Beds of Jamsavali, M. P.,India. Int. J. Recent Sci. Res. 11(05). 38579-38583.2020.

[11] Cook C. I. E. (1958). The flora of the presidency of Bombay. Botanical Survey of India, Culcutta (Reprint 1967) Vol.I, II, \& III.1958.

[12] Hutchinson J. (1959). In: The families of flowering plants (Third Edition) Koenigstein Vol. I \& II.1959.

[13] Kumar A. S. (1984). Ph. D. Thesis, Nagpur University, Nagpur.1984.

[14] Rendle A. B. (1963). In: Classification of flowering plants, Vol. II, Cambridge.1963. 